\title{
TFA catalyzed sequential amination/annulation/aromatization reaction of 2-propynyl-1.3-dicarbonyl compounds with amines: a new one-pot approach to functionalized pyrroles
}

\author{
Ayhan S. Demir*, Asuman Aybey, and Metin Kayalar \\ Department of Chemistry, Middle East Technical University 06531 Ankara Turkey \\ E-mail: asdemir@metu.edu.tr
}

(received 13 Jun 05; accepted 03 Oct 05; published on the web 09 Oct 05)

\begin{abstract}
Highly flexible and efficient syntheses of 1,2,3,5-substituted pyrroles starting from 2-propynyl1,3-dicarbonyl compounds and amines are presented. TFA catalyzed formation of the pyrroles is suggested to proceed through sequential amination of the carbonyl compounds followed by regioselective 5-exo-dig cyclization of the enaminone intermediate and aromatization.
\end{abstract}

Keywords: Amination, cyclization, TFA, 2-propynyl-1,3-dicarbonyls, pyrroles

\section{Introduction}

Pyrrole derivatives are very important compounds as they occur in a large number of natural products and display a variety of physiological activities ${ }^{1}$ in particular, 1,2,3,5-tetrasubstituted pyrrole derivatives $^{2}$ are biologically active and have been proven to display antibacterial, ${ }^{3}$ antiviral, $^{4}$ anti-inflammatory ${ }^{5}$ and antioxidant activities and to inhibit cytokine-mediated

diseases. ${ }^{6}$ Additionally, they have been found to show potent inhibiting platelet aggregation ${ }^{7}$ and antihypertensive activities. ${ }^{8}$

1,3-Dicarbonyl compounds are versatile intermediates for the synthesis of pyrrole derivatives. ${ }^{9}$ Pioneering work on the synthesis of pyrroles from 1,3-dicarbonyl compounds was carried out by Hantzsch in 1890. Many studies have been published on the synthesis of pyrroles using the principle of Hantzsch's method starting from 1,3-dicarbonyl compounds. ${ }^{10}$

Recently, Arcadi et al. ${ }^{11}$ described the synthesis of chiral 1,2,3,5-substituted pyrrole derivatives via gold catalyzed amination/annulation reactions of 2-propynyl-1,3-dicarbonyl compounds. Pyrroles with the same substitution pattern were synthesized by Müller et al. in good yields in a one-pot, three-step, four-component process. ${ }^{12}$ Dovey et al has shown that functionalized pyrroles can be efficiently prepared using a two-step sequence. This sequence involves the propargylation of secondary enaminones using $n$-BuLi and propargyl bromide, 
followed by intramolecular hydroamination catalysed by silver nitrate. ${ }^{13}$ Multicomponent coupling reactions furnished pyrroles is as well documented by Balme. ${ }^{14}$

As we have described in previous papers, we have designed a convenient route to 1,2- (A), 1,2,3- (B) substituted pyrrole rings from amines, amino alcohols and amino acids with simple accessible haloenones. ${ }^{15}$ We also described the synthesis of 1,2,3,5-substituted pyrroles (C) through enamines from 2-(2-bromoallyl)-1,3-dicarbonyl compounds (Figure. 1). ${ }^{16}$

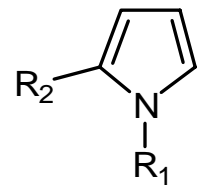

A<smiles>[R3]c1ccn([R1])c1[R]</smiles>

B

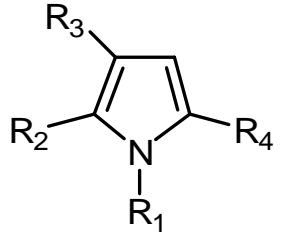

C

\section{Figure 1}

In many recent studies on the construction of the pyrrole ring, attack of nitrogen to the activated triple bond is the original idea for the pyrrole ring closure. ${ }^{17}$ This is valid for the construction of other heterocyclic five-membered rings in many recent studies. This attack may lead to either 5-exo-dig or 5-endo-dig type cyclization according to the number of carbon atoms between nitrogen and triple bond (Fig. 2).
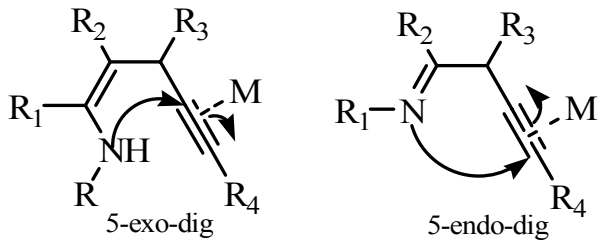

Figure 2

Synthesis of pyrroles in high yields with minimum number of steps through catalytic reaction are highly desired. In this work we are describing an efficient one-pot two component synthesis of 1,2,3,5-tetrasubstituted pyrrole derivatives through acid catalyzed cyclization reaction.

\section{Results and Discussion}

The strategy for the synthesis of 1,2,3,5-tetrasubstituted pyrrole derivatives is to find out new and easily available acyclic precursors and then to develop practical and flexible cyclization method. For this purpose 2-propynyl-1,3-dicarbonyl compounds, which are available via the $\alpha$ alkylation of 1,3-dicarbonyl compounds with propargyl halide, are chosen as an acyclic 
precursor. The formation of enaminone from 1,3-dicarbonyl compounds followed by cyclization should afford desired pyrrole ring. The most important part is to find out an appropriate 5-exodig type cyclization method for construction of pyrrole ring.

For the alkylation of 1,3-dicarbonyl compounds 1a-d NaH/THF at RT the best conditions were found concerning the yield of reaction. As shown in Table1 the 2-propynyl-1,3-dicarbonyl compounds 2a-d are obtained in $62-77 \%$ yield. The yields being moderate is due to the steric interference of the substituents on the dicarbonyl compounds as well as effect of dialkylation. Although this problem could not be sorted out completely, it was minimized by means of addition of propargyl bromide in small portions to deprotonated 1,3-dicarbonyl compounds.

In the first part of this study we aimed to synthesize the desired pyrrole derivatives by conversion of 2-propynyl-1,3-dicarbonyl compounds to its enaminones followed by metal mediated cyclization. For this purpose the enaminone $\mathbf{4}$ is synthesized through simple condensation reaction of 1.3-dicarbonyl compound $\mathbf{2 a}$ with $(R)$-phenylethylamine $((R)$-3a) in the presence of catalytic amount of $p-\mathrm{TsOH}$. Then the enaminone is reacted with catalytical amount of $\mathrm{Cu}(\mathrm{OAc})_{2}$ in 1,2-dichloroethane and pyrrole derivative $(R)-5 \mathbf{a}$ is obtained in $70 \%$ yield after purification (Scheme 1).

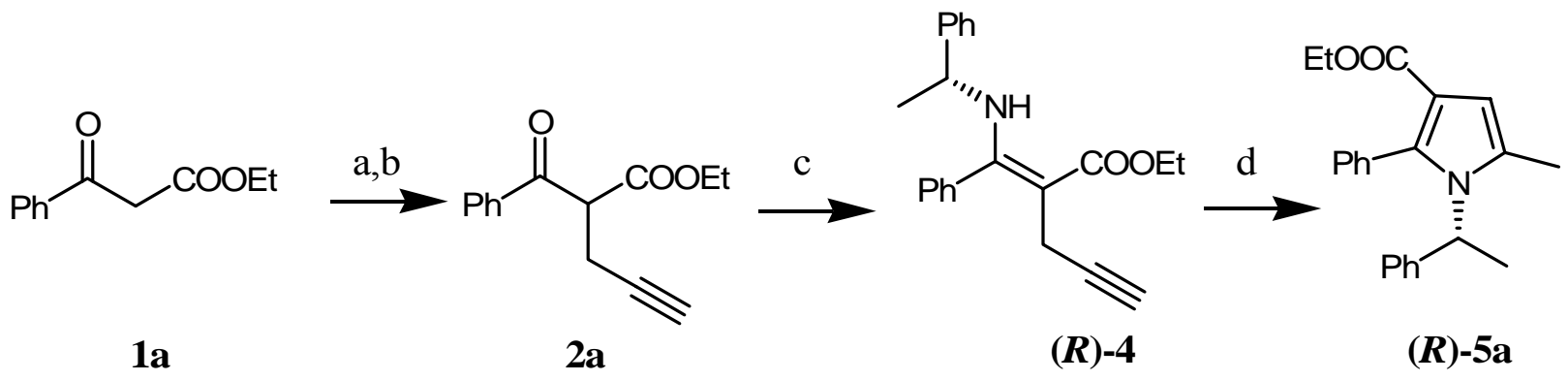

Scheme 1. a) NaH, THF; b) Propargylbromide; c) (R)-Phenylethanamine, $p$-TsOH, benzene, reflux; d) $\mathrm{Cu}(\mathrm{OAc})_{2}$, 1,2-Dichloroethane.

The attack of nitrogen on the carbon atom that leads to 5-exo-dig type cyclization which leads to pyrrole derivative 5a and this was only the product, the rest of the materials were the unreacted starting materials. No 6-endo-dig type cyclization product was observed.

The $p$-TsOH catalyzed reaction of $2 \mathbf{a}$ with $3 \mathbf{a}$ also furnished the pyrrole $5 \mathbf{a}$ in $7 \%$ yield together with 4 (Scheme 1).

The idea of combining the enaminone formation with cyclization step prompted us to carry out the conversion with one single step starting from 2-propynyl-1,3-dicarbonyl compounds. After this result we carried out the pyrrole formation reaction by using different amount of $p$ $\mathrm{TsOH}$ in different reaction conditions but non of them furnished the pyrrole 5a in acceptable yields. We had little success in optimizing these yields. This reaction, although facile, does not generate high enough yields $(\sim 14 \%)$ to be synthetically useful. 
During the screening reactions to find acceptable conditions for the formation of enaminones and their cyclizations, we found that catalytical amount of TFA is able to convert enaminone to pyrrole. Since activation of triple bond is the main requirement for the attack of nitrogen, catalytic amount of TFA was used as proton source for both activation of triple bond and catalysis of enaminone formation.

The test reaction of $1 \mathrm{mmol}$ 2-propynyl-1,3-dicarbonyl compounds 2 a was dissolved in benzene. $1.2 \mathrm{mmol}$ amine 3a together with (0.01 equivalent) TFA was added to the stirring mixture and refluxed for 15 hours by using Dean-Stark trap. The formation of products was monitored by TLC using 1:10 ethyl acetate:hexane solvent system. The pyrrole derivative 5a was isolated in 69\% yield after purification (Scheme 2).<smiles>[R]C(=O)C(CC#C)C([R])=O</smiles>

2a-e

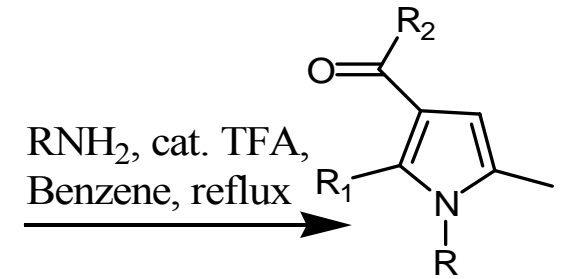

5a-m

\section{Scheme 2}

Using the same procedure various 2-propynyl-1,3-dicarbonyl compounds are refluxed with amine for 12-15 $\mathrm{h}$ and pyrrole derivatives $\mathbf{5 b}$-m were synthesized in high yields. The results of TFA catalyzed cyclization of 2-propynyl-1,3-dicarbonyl compounds are summarized in Table 1. In case of $(S)-5 \mathbf{l}$ and $(S)-5 \mathbf{m}$ the optical purity of the products was compared with the corresponding racemic compounds (rac-5l and rac-5m) using chiral HPLC column and it showed that the formation of a pyrroles $(S)-5 \mathbf{l}$ and $(S)-5 \mathbf{m}$ works without racemization. 

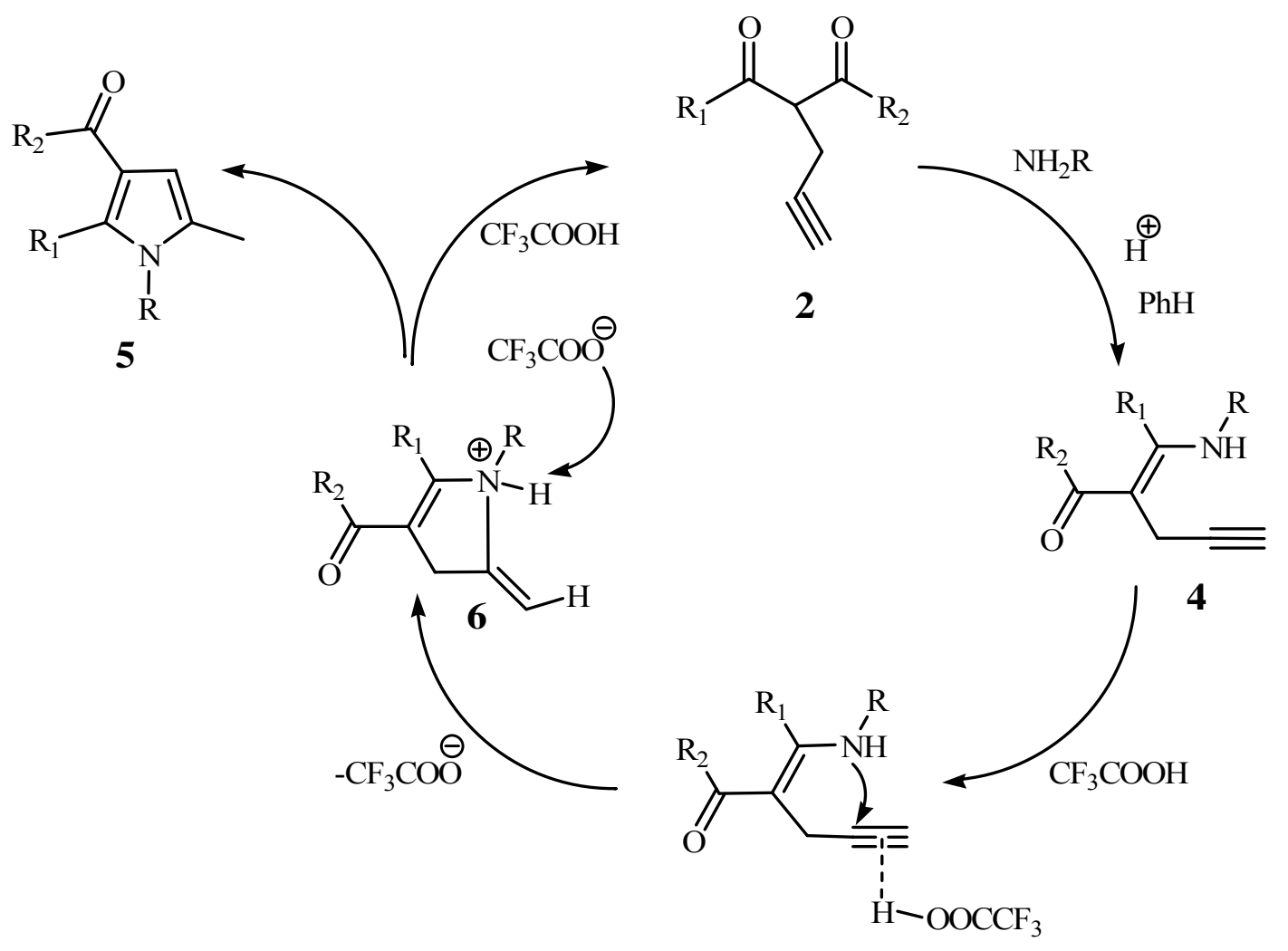

\section{Scheme 3}

The mechanism in operation is assumed to involve the TFA catalyzed formation of enaminone, then attack of nitrogen to triple bond affecting hydroamination and affording cyclic intermediate 6 (Scheme 3). This initial step is followed by rearrangement to afford pyrrole 5 . The attack of nitrogen on the triple bond often requires high activation energy. ${ }^{17 a}$ To overcome this drawback, triple bond is activated by the TFA. This mechanism is consistent with the generally accepted mechanism of nucleophilic addition to metal-activated carbon-carbon multiple bonds. $^{11 \mathrm{a}, \mathrm{b}}$

In summary the condensation reaction of 2-propynyl-1,3-dicarbonyl compounds with amines catalyzed by TFA represents a new general one-pot entry into fuctionalized pyrroles. The formation of the pyrroles is suggested to proceed through the sequential amination of carbonyl compounds followed by regioselective 5-exo-dig cyclization of the enaminone intermediate and aromatization reaction. The reaction requires a catalyst. TFA is the most efficient and selective catalysts and its application is general, but $\mathrm{Cu}(\mathrm{OAc})_{2}$ is also efficient catalysts when enaminones are used. 
Table 1. Acid catalyzed synthesis of pyrrole derivatives

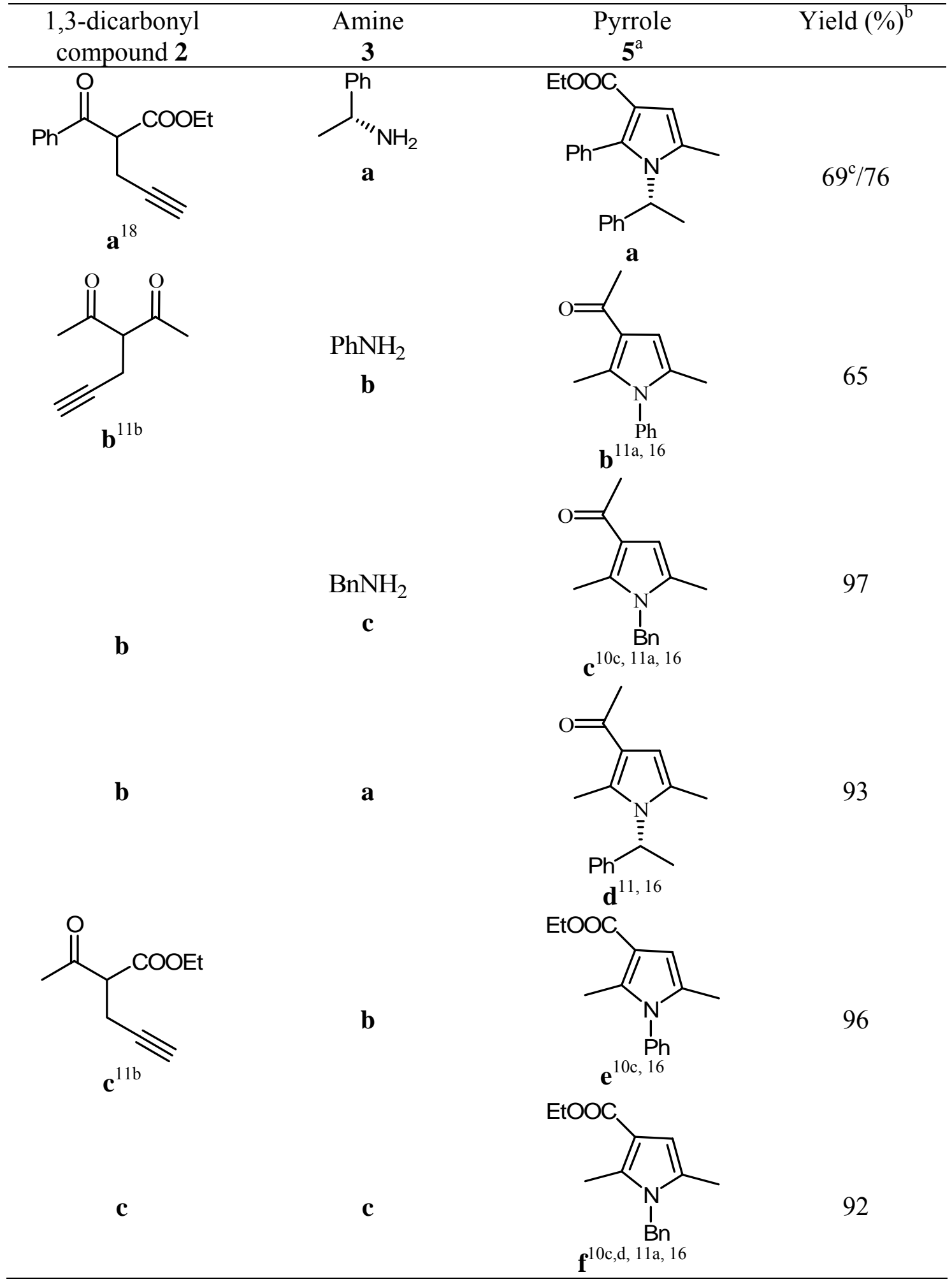


Table 2. Continued

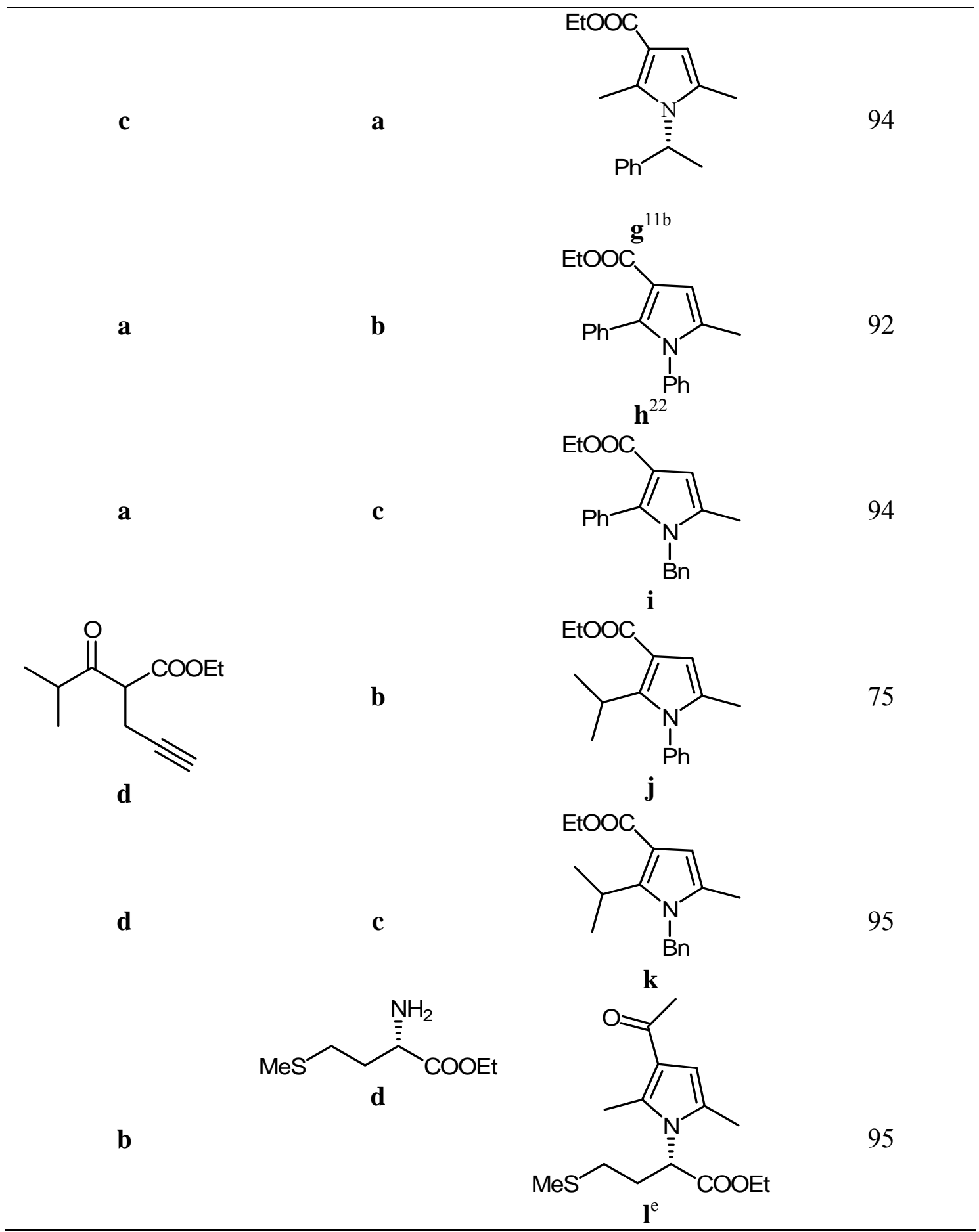


Table 3. Continued

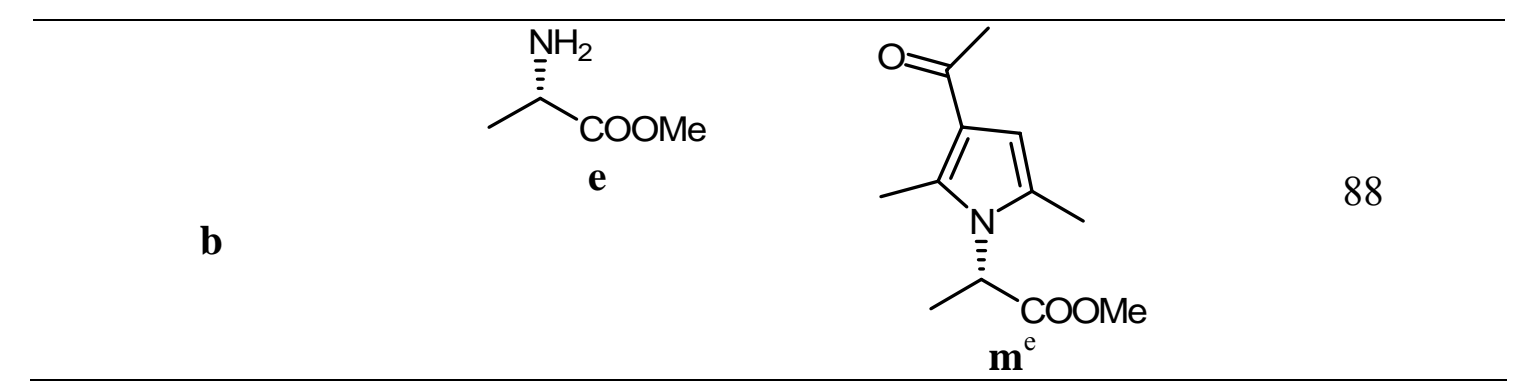

a) The known compounds have been identified by comparison of spectral data with those reported in the literature. b) Isolated yields. c) $\mathrm{Cu}(\mathrm{OAc})_{2}$ catalyzsd reaction. e) Optical purity is determined by chiral HPLC analysis (Chiral pack AD column, UV detection at $220 \mathrm{~nm}, 90 / 10 \mathrm{i}$ hexane/isopropanol, flow rate $0.75 \mathrm{ml} / \mathrm{min}$ ).

\section{Experimental Section}

\section{General Procedures}

NMR spectra were recorded on a Bruker DPX 400. Chemical shifts $\delta$ are reported in ppm relative to $\mathrm{CHCl}_{3}\left({ }^{1} \mathrm{H}: \delta=7.27\right), \mathrm{CDCl}_{3}\left({ }^{13} \mathrm{C}: \delta=77.0\right)$ and $\mathrm{CCl}_{4}\left({ }^{13} \mathrm{C}: \delta=96.4\right)$ as internal standards. IR spectra were recorded on a Perkin Elmer 1600 FTIR series instrument.

Column chromatography was conducted on silica gel $60(40-63 \mu \mathrm{m})$. TLC was carried out on aluminum sheets pre-coated with silica gel $60 \mathrm{~F}_{254}$ (Merck), and the spots were visualized with UV light $(\lambda=254 \mathrm{~nm})$. Enantiomeric purity were determined by HPLC and LC-MS analysis using a Thermo Finnigan Surveyor equipped with an appropriate chiral phase column, as described in the footnote of the table. Optical rotations were measured with a Krüss P3002RS automatic polarimeter.

\section{General procedure for alkylation of 1,3-dicarbonyl compounds}

1.3-Dicarbonyl compound $(5.0 \mathrm{mmol})$ was dissolved in $10 \mathrm{THF}$ and stirred. Under $\mathrm{Ar}$ atmosphere $\mathrm{NaH}(120 \mathrm{mg}, 5.0 \mathrm{mmol})$ was added carefully and stirred for 2-3 hours. Subsequently propargyl bromide $(655 \mathrm{mg}, 5.0 \mathrm{mmol}$ ) was added in 4 or 5 portions during 4 hours. The formation of products was monitored by TLC (by using 1:7 ethyl acetate:hexane solvent system).

After completion of the reaction, unreacted $\mathrm{NaH}$ was neutralized with water, reaction mixture was acidified with 2-3 drops of concentrated $\mathrm{HCl}$, extracted with ethyl acetate three times (3x30), dried $\left(\mathrm{MgSO}_{4}\right)$, and concentrated under reduced pressure. Further purification was achieved by flash column chromatography (1:7 ethyl acetate:hexane) to afford the alkylated 1,3dicarbonyl compounds.

Ethyl 2-(isobutyryl)pent-4-ynoate (2d). Ethyl 4-methyl-3-oxopentanoate (980 mg $5.0 \mathrm{mmol}$ ) was alkylated according to the general procedure and the product is obtained as an oil $(628 \mathrm{mg}$, 
$64 \%$ ) after purification by column chromatography. Alkylated form exists in both keto and enol form according to the ${ }^{1} \mathrm{H}-\mathrm{NMR}$ spectrum. Yellow oil, IR(neat):3050-2850, 2110, 1740, $1710 \mathrm{~cm}^{-}$ ${ }^{1} .{ }^{1} \mathrm{H}-\mathrm{NMR}\left(400 \mathrm{MHz}, \mathrm{CDCl}_{3}\right)$ : 1.03-1,07 (m, 6H), $1.18(\mathrm{t}, \mathrm{J}=7 \mathrm{~Hz}, 3 \mathrm{H}), 1.94(\mathrm{t}, \mathrm{J}=2.7 \mathrm{~Hz}, 1 \mathrm{H})$, 2.59-2.62 (m, 1H), 2.80-2.83 (m, 1H), $3.41(\mathrm{~d}, \mathrm{~J}=7.2 \mathrm{~Hz}, 1 \mathrm{H}), 3.83$ (t, J=3.2 Hz, 1H), 4.10 (q, 3.2 $\mathrm{Hz}, 2 \mathrm{H})$. Anal. Calcd for $\mathrm{C}_{11} \mathrm{H}_{16} \mathrm{O}_{3}$ (196.24): C 67.32, $\mathrm{H}$ 8.22; found: C 67.55, H, 8.45.

(Z)-Ethyl 2(((R)-1-phenylethylamino)(phenyl)methylene)pent-4-ynoate (4). Ethyl 2(benzoyl)pent-4-ynoate (300 mg,1.3 mmol) was condensed with $(R)$-phenylethylamine (158 $\mu \mathrm{L}$, $1.56 \mathrm{mmol}$ ) in the presence of catalytic amount of $p-\mathrm{TsOH}$ in benzene (10) by using Dean-Stark trap to remove water from the medium. The formation of products was monitored by TLC (by using 1:10 ethyl acetate:hexane solvent system). After completion of the reaction, the reaction mixture extracted with ethyl acetate three times $(3 \times 10)$, dried $\left(\mathrm{MgSO}_{4}\right)$, and concentrated under reduced pressure. Then purification performed via flash column chromatography (1:10 ethyl acetate:hexane solvent system) to isolate (Z)-Ethyl 2(((R)-1phenylethylamino)(phenyl)methylene)pent-4-ynoate as a yellow oil (347 $\mathrm{mg}, 80 \%)$. IR(neat):3035-2917, 2069, 1649, 1591, 1562 $\mathrm{cm}^{-1} .{ }^{1} \mathrm{H}-\mathrm{NMR}\left(400 \mathrm{MHz}, \mathrm{CDCl}_{3}\right): \delta(\mathrm{ppm}) 1.35$ (t, $\mathrm{J}=7.2 \mathrm{~Hz}, 3 \mathrm{H}), 1.38$ (d, J=6.9 Hz, 3H), 1.93-1.95 (br, 1H), 2.55 (dd, J=2.7 Hz, J=18.2 Hz, B part of A-B system, 1H), 2.62 (dd, J=2.7 Hz, J=18.2 Hz, A part of A-B system, 1H), 4.02 (q, J=19 $\mathrm{Hz}, 2 \mathrm{H}), 4.15-4.20(\mathrm{~m}, 2 \mathrm{H}), 6.66(\mathrm{~d}, \mathrm{~J}=7.6 \mathrm{~Hz}, 1 \mathrm{H}), 6.91(\mathrm{~d}, \mathrm{~J}=7.0 \mathrm{~Hz}, 1 \mathrm{H}), 7.06-7.21(\mathrm{~m}, 4 \mathrm{H})$, 7.24-7.31 (m, 2H), 7.34-7.40 (m, 1H), $9.53(\mathrm{~d}, \mathrm{~J}=9.0 \mathrm{~Hz}, 1 \mathrm{H})$. Anal. Calcd for $\mathrm{C}_{22} \mathrm{H}_{23} \mathrm{NO}_{2}$ (333.42): C 79.25, H 6.95, N, 4.20; found: C 79.11, H, 6.41, N, 4.43.

(R)-Ethyl 5-methyl-2-phenyl-1-(1-phenylethyl)-1H-pyrrole-3-carboxylate (5a). (Z)-Ethyl 2(((R)-1-phenylethylamino)(phenyl)methylene)pent-4-ynoate (4) $(150 \mathrm{mg}, 0.45 \mathrm{mmol})$ was dissolved in 1,2-dichloroethane (6) and $\mathrm{Cu}(\mathrm{OAc})_{2}(16 \mathrm{mg}, 0.09 \mathrm{mmol})$ was added. Then the resulting mixture was refluxed for 6 hours. The formation of products was monitored by TLC ( by using 1:7 ethyl acetate:hexane solvent system). After completion of the reaction, the reaction mixture extracted with diethyl ether three times (3x5), dried $\left(\mathrm{MgSO}_{4}\right)$, and concentrated under reduced pressure. Then purification performed via flash column chromatography (1:10 ethyl acetate:hexane) to afford (R)-Ethyl 5-methyl-2-phenyl-1-(1-phenylethyl)-1H-pyrrole-3carboxylate as a yellow oil ( $114 \mathrm{mg}, 76 \%$ yield). $[\alpha]_{\mathrm{D}}^{20}:+185.1$ (c $\left.0.47, \mathrm{CHCl}_{3}\right)$. IR(neat): 3040-2975, 1680, $1533 \mathrm{~cm}^{-1} .{ }^{1} \mathrm{H}-\mathrm{NMR}\left(400 \mathrm{MHz}, \mathrm{CDCl}_{3}\right): \delta(\mathrm{ppm}) 1.09(\mathrm{t}, \mathrm{J}=7.0 \mathrm{~Hz}, 3 \mathrm{H}), 1.77$ (d, J=7.1 Hz, 3H), 1.88 (s, 3H), 4.06 (q, J=7.1 Hz, 2H), 5.29 (q, J=7.0 Hz, 1H), 6.38 (s, 1H), 7.0 $(\mathrm{d}, \mathrm{J}=7.5 \mathrm{~Hz}, 2 \mathrm{H}), 7.2-7.43(\mathrm{~m}, 8 \mathrm{H}) .{ }^{13} \mathrm{C}-\mathrm{NMR}\left(\mathrm{CDCl}_{3}\right): \delta$ (ppm) 14.1, 14.2, 19.1, 53.2, 58.9, 110.5, 112.6, 125.9, 127.1, 127.9, 128.2, 128.3, 128.5, 128.7, 128.8, 129.1, 130.1, 130.8, 133.1, 139.1, 141.2, 164.4. Anal. Calcd for $\mathrm{C}_{22} \mathrm{H}_{23} \mathrm{NO}_{2}(333.4)$ : C 79.25, H 6.95, N, 4.20; found: $\mathrm{C}$ 79.35, H, 6.87, N, 4.05 .

\section{General procedure for the acid catalyzed cyclization reaction}

Alkylated 1,3-dicarbonyl compound (1 mmol) was dissolved in benzene (10). Corresponding amine $(1.2 \mathrm{mmol})$ together with TFA $(77.5 \mu \mathrm{L}, 0.01 \mathrm{mmol})$ was added to the stirring mixture and 
refluxed 12-15 hours by using Dean-Stark trap. The formation of products was monitored by TLC (by using 1:10 ethyl acetate:hexane solvent system).

After completion of the reaction, the reaction mixture extracted with ethyl acetate three times (3x10), dried $\left(\mathrm{MgSO}_{4}\right)$, and concentrated under reduced pressure. When further purification needed, flash column chromatography was performed (1:10 ethyl acetate:hexane) to afford the pyrrole derivatives.

Ethyl 1-benzyl-5-methyl-2-phenyl-1H-pyrrole-3-carboxylate (5i). Yellow solid (302 mg, 94\%), mp 88-90 C. IR(KBr): 3035-2985, 1685, 1536, $1420 \mathrm{~cm}^{-1} .{ }^{1} \mathrm{H}-\mathrm{NMR}\left(400 \mathrm{MHz}, \mathrm{CDCl}_{3}\right): \delta$ $=1.14(\mathrm{t}, \mathrm{J}=7.1 \mathrm{~Hz}, 3 \mathrm{H}), 2.04(\mathrm{~s}, 3 \mathrm{H}), 4.01(\mathrm{q}, \mathrm{J}=7.1 \mathrm{~Hz}, 2 \mathrm{H}), 4.83(\mathrm{~s}, 2 \mathrm{H}), 6.40(\mathrm{~s}, 1 \mathrm{H}), 6.75(\mathrm{~d}$, $\mathrm{J}=7.3 \mathrm{~Hz}, 2 \mathrm{H}), 7.11-7.23(\mathrm{~m}, 8 \mathrm{H}) .{ }^{13} \mathrm{C}-\mathrm{NMR}\left(100 \mathrm{MHz}, \mathrm{CDCl}_{3}\right): \delta=12.4,14.2,47.6,59.0$, 109.2, 112.9, 125.6, 127.2, 127.7, 128.1, 128.7, 128.8, 130.7, 132.3, 137.8, 138.5, 164.5, Anal. Calcd for $\mathrm{C}_{21} \mathrm{H}_{21} \mathrm{NO}_{2}$ (319.4): C, 78.97; H, 6.63; N, 4.39. Found: C, 78.81; H, 6.77; N, 4.58.

Ethyl 2-isopropyl-5-methyl-1-phenyl-1H-pyrrole-3-carboxylate (5j). Orange solid (204 mg, $75 \%$ ), mp $89^{\circ} \mathrm{C}$. IR(KBr): 3025-2965, 1690, 1540, $1420 \mathrm{~cm}^{-1} .{ }^{1} \mathrm{H}-\mathrm{NMR}\left(400 \mathrm{MHz}, \mathrm{CDCl}_{3}\right): \delta=$ $1.14(\mathrm{~d}, \mathrm{~J}=7.1 \mathrm{~Hz}, 6 \mathrm{H}), 1.26$ (t, J=7.1 Hz, 3H), 1.80 (s, 3H), 2.87-3.00 (m, 1H), 4.17 (q, J=7.2 $\mathrm{Hz}, 2 \mathrm{H}), 6.26(\mathrm{~s}, 1 \mathrm{H}), 7.3(\mathrm{~d}, \mathrm{~J}=7.3 \mathrm{~Hz}, 2 \mathrm{H}), 7.33-7.41(\mathrm{~m}, 3 \mathrm{H}) .{ }^{13} \mathrm{C}-\mathrm{NMR}\left(100 \mathrm{MHz}, \mathrm{CDCl}_{3}\right): \delta$ $=12.6,14.6,20.7,26.8,59.0,108.9,110.7,127.7,128.5,128.6,128.7,129.1,138.7,145.5$, 164.7. Anal. Calcd for $\mathrm{C}_{17} \mathrm{H}_{21} \mathrm{NO}_{2}$ (271.35): C, 75.25; H, 7.80; N, 5.16. Found: C, 75.41; H, 7.79; N, 4.38 .

Ethyl 1-benzyl-2-isopropyl-5-methyl-1H-pyrrole-3-carboxylate (5k).Yellow oil (271 mg, 95\%). IR(neat): 3030-2945, 1688, 1543, $1430 \mathrm{~cm}^{-1} .{ }^{1} \mathrm{H}-\mathrm{NMR}\left(400 \mathrm{MHz}, \mathrm{CDCl}_{3}\right): \delta=1.17$ (d, $\mathrm{J}=7.2 \mathrm{~Hz}, 6 \mathrm{H}), 1.27(\mathrm{t}, \mathrm{J}=7.1 \mathrm{~Hz}, 3 \mathrm{H}), 2.0(\mathrm{~s}, 3 \mathrm{H}), 3.34-3.39(\mathrm{~m}, 1 \mathrm{H}), 4.16(\mathrm{q}, \mathrm{J}=7.1 \mathrm{~Hz}, 2 \mathrm{H}), 5.1$ $(\mathrm{s}, 2 \mathrm{H}), 6.26(\mathrm{~s}, 1 \mathrm{H}), 6.8(\mathrm{~d}, \mathrm{~J}=7.5 \mathrm{~Hz}, 2 \mathrm{H}), 7.13-7.23(\mathrm{~m}, 3 \mathrm{H}) .{ }^{13} \mathrm{C}-\mathrm{NMR}\left(100 \mathrm{MHz}, \mathrm{CDCl}_{3}\right): \delta=$ 12.2 , 14.6, 20.7, 25.9, 43.8, 47.5, 59.0, 109.4, 110.6, 125.4, 127.3, 127.6, 128.1, 128.5, 128.7, 137.7, 144.6, 164.9. Anal. Calcd for $\mathrm{C}_{18} \mathrm{H}_{23} \mathrm{NO}_{2}$ (285.38): C, 75.76; H, 8.12; N, 4.91. Found: C, $75.58 ; \mathrm{H}, 8.28 ; \mathrm{N}, 4.68$.

(S)-Ethyl 2-(3-acetyl-2,5-dimethyl-1H-pyrrol-1-yl)-4-(methylthio)butanoate (5l). Yellow oil (283 mg, 95\%). [ $\alpha]_{\mathrm{D}}{ }^{20}:-21.5$ (c 0.65 ), $\mathrm{CHCl}_{3}$ ). IR(neat): 3010, 2358, 1733, 1646, $1589 \mathrm{~cm}^{-1}$. ${ }^{1} \mathrm{H}-\mathrm{NMR}\left(400 \mathrm{MHz}, \mathrm{CDCl}_{3}\right): \delta=1.16-1.20(\mathrm{~m}, 3 \mathrm{H}), 2.00(\mathrm{~s}, 3 \mathrm{H}), 2.13(\mathrm{~s}, 3 \mathrm{H}), 2.27(\mathrm{~s}, 3 \mathrm{H})$, 2.41-2.54 (m, 4H), $4.13(\mathrm{q}, \mathrm{J}=7.1 \mathrm{~Hz}, 2 \mathrm{H}), 4.95(\mathrm{t}, \mathrm{J}=7.1 \mathrm{~Hz} 1 \mathrm{H}), 6.11(\mathrm{~s}, 1 \mathrm{H}) .{ }^{13} \mathrm{C}-\mathrm{NMR}(100$ $\left.\mathrm{MHz}_{\mathrm{CDCl}}\right): \delta=12.1,13.0,14.1,21.6,27.4,28.6,29.5,54.0,60.7,108.2,120.5,127.6,135.6$, 168.7, 193.2. Anal. Calcd for $\mathrm{C}_{15} \mathrm{H}_{23} \mathrm{NO}_{3} \mathrm{~S}(297.41)$ : C, 60.58; H, 7.79; N, 4.71. Found: C, 60.37; H, 7.68; N, 4.53 .

(S)-Methyl 2-(3-acetyl-2,5-dimethyl-1H-pyrrol-1-yl)propanoate (5m). Yellow oil (262 mg, $88 \%$ ). $[\alpha]_{\mathrm{D}}{ }^{20}:-41.2$ (c $0.42, \mathrm{CHCl}_{3}$ ). IR(neat): 3007, 2360, 1744, 1648, $1520 \mathrm{~cm}^{-1}$. ${ }^{1} \mathrm{H}-\mathrm{NMR}$ $\left(400 \mathrm{MHz} \mathrm{CDCl}_{3}\right): \delta=1.57(\mathrm{~d}, \mathrm{~J}=7.3 \mathrm{~Hz}, 3 \mathrm{H}), 2.10(\mathrm{~s}, 3 \mathrm{H}), 2.28(\mathrm{~s}, 3 \mathrm{H}), 2.43(\mathrm{~s}, 3 \mathrm{H}), 3.68(\mathrm{~s}$, $3 \mathrm{H}), 4.83(\mathrm{q}, \mathrm{J}=7.3 \mathrm{~Hz}, 1 \mathrm{H}), 6.15(\mathrm{~s}, 1 \mathrm{H}) .{ }^{13} \mathrm{C}-\mathrm{NMR}\left(100 \mathrm{MHz}, \mathrm{CDCl}_{3}\right): \delta=12.1,12.8,17.1,28.5$, 52.3, 52.8, 109.3, 120.5, 127.3, 134.7, 170.9, 194.9. Anal. Calcd for $\mathrm{C}_{12} \mathrm{H}_{17} \mathrm{NO}_{3}(297.41)$ : C, 64.55; H, 7.67; N, 6.27. Found: C, 64.33; H, 7.78; N, 6.11. 


\section{Acknowledgements}

The financial support from the Scientific and Technical Research Council of Turkey (TUBITAK), the Turkish Academy of Sciences (TÜBA), the Turkish State Planning Organization (for LC-MS), the Middle East Technical University is gratefully acknowledged.

\section{References}

1. (a) Yates, F. S. In Comprehensive Heterocyclic Chemistry; Boulton, A. J.; McKillop, A. Eds; Pergamon: Oxford, 1984; Vol 2, Part 2A, p 511. (b) Jones, R. A. In Pyrroles, Part II, The Synthesis, Reactivity and Physical Properties of Substituted Pyrroles; Wiley and Sons: New York, 1992. (c) Corvo, M. C.; Pereira, M. A. Tetrahedron Lett. 2002, 43, 455.

2. Tanaka, T.; Oba, T.; Okamure, N.; Watanabe, K.; Kurozumi, S.; Naruchi, T. Synthetic Commun. 1980, 10, 773.

3. Daidone, G.; Maggio, B.; Schillari, D. Pharmazie 1990, 45, 441.

4. (a) Almerico, A. M.; Diana, P.; Barraja, P.; Dattolo, G.; Mingoia, F.; Loi, A. D.;Scintu, F.; Milia, C.; Puddu, I.; La Colla, P. Farmaco 1998, 53, 33. (b) Almerico, A. M.; Diana, P.; Barraja, P.; Dattalo, G.; Mingoia, F.; Putzolu, M.; Perra, G.; Milia, C.; Musiu, C.; Marongiu M. E. Farmaco 1997, 52, 667.

5. (a) Kimura, T.; Kawara, A.; Nakao, A.; Ushiyama, S.; Shimozato, T.; Suzuki, K.PCT Int. Appl. WO 0001688 A1 20000113, 2000. (b) Kaiser, D. G.; Glenn E. M. J. Pharm. Sci. 1972, $61,1908$.

6. Lehuede, J.; Fauconneau, B.; Barrier, L.; Ourakow, M.; Piriou, A.; Vierfond, J. M. Eur. J. Med. Chem. 1999, 34, 991.

7. Ohtsu, K.; Hoshina, K.; Jinba, M.; Mori, T.; Naruchi, S.; Hashimoto, Y. Blood Vessel 1979, 10,5 .

8. Tilford, C. H.; Hudak, W. J.; Lewis, R. J. Med. Chem. 1971, 14, 328.

9. (a) Jones, R. A.; Bean, G. P. In The Chemistry of Pyrroles, Blomquist, A. T.; Wasserman, H. H. Eds; Academic Press Inc.: London, 1977; Ch. 3 and 4. (b) Gilchrist, T. L. J. Chem. Soc., Perkin Trans. 1 2001, 2491.

10. (a) Hantzsch, A. Ber. 1890, 23, 1474. (b) Cheng, L.; Lightner, D. A. Synthesis 1999, 1, 46. (c) Ferraz, H. M. C.; Pereira, F. L. C.; Leite, F. S.; Nunes, M. R. S.; Payret-Arrua, M. E. Tetrahedron 1999, 55, 10915. (d) Ferraz, H. M. C.; de Oliveira, E. O.; Payret-Arrua, M. E.; Brandt, C. A. J. Org. Chem. 1995, 60, 7357.

11. (a) Arcadi, A.; Di Giuseppe, S.; Marinelli, F.; Rossi, E. Adv.Synth. Catal. 2001, 343, 443; (b) Arcadi, A.; Di Giuseppe, S.; Marinelli, F.; Rossi, E. Tetrahedron: Asymmetry 2001, 12, 2715.

12. Braun, R. U.; Zeitler, K.; Müller, T. J. J. Org. Lett. 2001, 3, 3297.

13. Robinson, R. S.; Dovey, M. C.; Gravestock, D. Tetrahedron Lett. 2004, 45, 6787. 
14. Balme, G. Angev. Chem. Int. Ed. 2004, 43, 6238.

15. (a) Demir, A. S.; Akhmedov, I. M.; Sesenoglu, O.; Alpturk, O.; Apaydin, S.; Gercek, Z.; Ibrahimzade, N. J. Chem. Soc., Perkin Trans. 1 2001, 1162. (b) Aydogan, F.; Demir, A. S. Tetrahedron:Asymmetry 2004, 15, 259. (c) Aydogan, F.; Demir, A. S. Tetrahedron 2005, $61,3019$.

16. Demir, A. S.; Akhmedov, I. M.; Sesenoglu, O. Tetrahedron 2002, 58, 9793.

17. (a) Müller, T. E.; Beller M. Chem. Rev. 1998, 98, 675. (b) Hiroya, K.; Itoh, S.; Sakamoto, T. J. Org. Chem. 2004, 69, 1126. (c) Knochel, P.; Rodriguez, A. L.; Koradin, C.; Dohle, W. Angew. Chem. Int. Ed. 2000, 39, 2488. (d) Gabriele, B.; Salerno, G.; Fazio, A.; Bossio, M. R. Tetrahedron Lett. 2001,42, 1339. (e) Gabriele, B.; Salerno, G.; Fazio, A. J. Org. Chem. 2003, 68, 7853. (f) Gevorgyan, V.; Sromek, A. W.; Kel'in, A. V. J. Am. Chem. Soc. 2001, 123, 5492.

18. Queignec, R.; Kirschleger, B.; Lambert, F.; Aboutaj, M. Synthetic Commun. 1988, 18(11), 1213.

19. Acharya, S. P.; Brown, H. C. J. Am. Chem. Soc. 1967, 89, 1925.

20. (a) Bhar, S.; Chaudhuri, S. K.; Sahu, S.G.; Panja, C. Tetrahedron 2001, 57, 9011. (b) Antonioletti, R.; Bonadies, F.; Orelli, R.; Scettri, A. Gazz. Chim. Ital. 1992, 122, 237.

21. Kazembe, T. C. G.; Taylor, D. A. Tetrahedron 1980, 36, 2125.

22. Martins, T. J.; Fowler, K.W.; Oliver, A.; Hertel, C.C. Preparation of novel yrroles as cyclic AMP-specific phosphodiesterase inhibitors. PCT Int. Appl. (2001), 151. 